\title{
Coopetition as a Strategic Enabler of Innovation in Transition Economies
}

\author{
Songül Zehir ${ }^{1}$ | Melike Zehir ${ }^{2}$ I Doğan Başar ${ }^{3}$
}

1 Asisst. Prof. Dr., Duzce University, Department of Business Administration

Duzce/Turkey ORCID: $0000-0002-5525-2438$

E-Mail: songulzehir@hotmail.com

2 PhD. Candidate., Yildiz

Technical University

Department of Business

Administration

Istanbul/Turkey

ORCID: 0000-0003-4700-8678

E-Mail

melikedogan1989@gmail.com

${ }^{3}$ Dr., HR Executive Director at

Central Bank of the Republic of

Turkey, Ankara/Turkey

ORCID: 0000-0002-7570-7444

E-Mail:

doganbasar@gmail.com

Corresponding Author: Melike Zehi

January 2022

Volume:19

Issue: 45

DOI: 10.26466//opusjsr.1063213

Citation:

Zehir, M., Zehir, S. and Başar, D.

(2022). Coopetition as a strategic enabler of innovation in transition economies. OPUSJournal of Society Research, 19(45),

\begin{abstract}
Transition economies have distinctive opportunities and challenges compared to other economies Innovation is among the major contributors for development and welfare in countries with transition economies. Limited sources, environmental forces, rapid changes in technology, cost and complexity of research drive organizations to form strategic alliances with their competitors and prefer innovation through coopetition. Transition economies with their unique characteristics compared to other economies and potential of achievable benefits from innovation require particular attention. This study identifies, describes and discusses the promising areas of research methods and perspectives about innovation through coopetition in transition economies. A comprehensive critical evaluation of the underlying dynamics of innovation through coopetition and innovation in transition economies, aided by bibliometric mapping and analysis showed the promising enabling potential of coopetition for innovation in challenging conditions of transition economies. The viable and beneficial coopetition ideas and approaches are identified, represented and discussed to enable effective innovation in transition economies. The main features and challenging aspects of these ideas and approaches are explained in details.
\end{abstract}

Key Words: Transition Economies, Innovation, Coopetition, Competitiveness.

Öz

Geçiş ekonomileri, diğer ekonomilere kıyasla ayırt edici firsatlar ve zorluklara sahiptir. İnovasyon, geçiş ekonomisi ülkelerinde kalkınma ve refaha katkı să̆layan başlıca unsurların başında gelmektedir. Sinırlı kaynaklar, çevresel faktörler, teknolojideki hızlı değişimler, araştırma faaliyetlerinin maliyetleri ve karmaşıklı̆̆ı kurumları rakipleriyle stratejik ortaklıklar kurmaya ve ortaklaşa rekabet yoluyla inovasyon yapmaya yöneltmektedir. Geçiş ekonomilerinin diğer ekonomilere göre özgün özellikleri ve inovasyonun bu ekonomilerde sağlayabileceği potansiyel faydalar kayda değerdir. Bu çalışma, geçiş ekonomilerinde ortaklaşa rekabet yoluyla inovasyon için öne çıkan araştırma yöntemleri ve bakış açılarımı ortaya çıkarmakta, tanımlamakta ve yorumlamaktadır. Ortaklaşa rekabet ile inovasyon üzerine çalışmalar ve geçiş ekonomilerinde inovasyon çalısmaları kapsamlı olarak ele alınarak temel dinamikler değerlendirilmiş, bibliyometrik analizin de katkılarıla ortaklaşa rekabet yoluyla geçiş ekonomilerinin zorlu koşullarında yapılabilecek inovasyonun umut verici potansiyeli görülmüştür. Geçiş ekonomilerinde etkin inovasyona olanak sağlayabilecek uygulanabilir ve faydalı ortaklaşa rekabet fikir ve yaklaşımları belirlenmiş, sunulmuş ve yorumlanmıştır. Bu fikir ve yaklaşımlar üzerine yapılacak çalışmalarda öne çıkan ve dikkat edilmesi gereken yönler detaylıca açıklanmıştır.

Anahtar Kelimeler: Geçiş Ekonomileri, Inovasyon, Ortaklaşa Rekabet, Rekabet Edilebilirlik 


\section{Introduction}

Continuous increase in competition in all over the world as a consequence of globalisation tends to speed up with increasing number of firms, changes in consumer preferences, emerging business models and advances in technology. In an atmosphere where the existence of companies heavily depends on their competitiveness and profits with rapidly changing conditions, firms have to determine new strategies and methods for sustainable development.

Innovation is described as realization of a new product (good or service), a process, a marketing method or a new organizational approach in intrafirm applications, business organizations or external relations. Advancing technologies, diversifying customer needs, emerging industrial fields, fluctuations in source costs and regulatory changes of governments make innovation essential. Innovation has a major impact on development and job creation (Sternberg \& Wennekers, 2005). Innovation both contributes to the national and regional development and welfare. According to Porter, there are three development stages of the economic situation of a country. The first stage is factor-based, where production is mainly based on land and unqualified labor. The second and the middle phase is investment-based, where manufacturing is more dependent on imported technology and capital. Through the development of local markets, there lies more flexibility and resources to move to the third and final stage: innovation-based economy. This stage is characterized by innovation and commercialisation of new technologies with high added value.

Coopetition is an emerging area of study that provides a number of benefits including fostered innovation. The term "coopetition" is used for the dynamic cases where two or more competing actors (within a firm or from different companies) are also collaborating for some common benefits (Bouncken, Gast, Kraus \& Bogers, 2015). There are four main outcomes of coopetition activities; namely, innovation, knowledge (sharing, creation and acquisition), firm performance and relations (access to resources, learning, fulfillment of goals and etc.) (Bengtsson \& Raza-Ullah, 2016).

The main drivers for innovation through coopetition are lack of sources, environmental forces, rapid change in technology, cost and complexity of research, access to value chains and development of highly specialized products (Krommendijk, 2016). As stated in the work of Ritala, Kraus \& Bouncken (2016), the core focuses for the research on coopetition and innovation are consequences-outcomes, tensions-dynamicsinteraction, value creation-appropriation and innovation in networks-ecosystems.

Transition economies, where there is a movement from central and planned economy to a market-based competitive economy, are environments with distinctive characteristics for innovation. Joining of foreign companies to a recently opened market, use of foreign direct investment (FDI) for development, privatization of public firms, transition from government regulated research and development (R\&D) to private companies-integrated open R\&D activities, increasing competition and challenges for local companies, changing policies, societal inequalities between rich and poor, inclusive innovation according to local needs, and cultural reactions to transformation started to gain interest of researchers.

This study investigates the possible strategies on innovation through coopetition in transition economies, with an in-depth critical evaluation of the innovation-centered works in the area of coopetition and in transition economies.

The studies on coopetition in the literature can be mainly classified as conceptual development studies (Loebbecke, Fenema \& Powell, 2016), mapping of critical success factors and variables for performance analysis (Petter, Resende, Júnior \& Horst, 2014), the main approaches and future challenges (Bengtsson \& Kock, 2014; Bouncken et al., 2015), drivers, process and outcomes (Bengtsson, Raza-Ullah \& Vanyushyn, 2016), including firm size related differences in drivers, advantages and disadvantages (Krommendijk, 2016). Although these studies have valuable contributions to the related area of study, there is 
lack of studies that critically evaluate the approaches in coopetition for innovation. There is an introductory study that focuses on innovation related coopetition, published in 2016 (Ritala et al., 2016), and numerous papers focusing on different aspects have later been added to the literature, expanding the area of study. Most of the related works mainly provide superficial insights in limited scopes and there is need for deriving the knowledge covering diverse efforts. In addition, critical evaluation of coopetition studies is rarely conducted to identify the adoptable approaches for specific sub fields including transition economies.

This paper is mainly on the identification of promising areas of research, adoptable methods and useful perspectives for innovation through coopetition in transition economies. The study contributes to the related literature by (a) detailed understanding of dispersed conditions for innovation in transition economies and mainly (b) identification, representation and discussion of suitable and advantageous ideas and approaches that can be adopted for innovation through coopetition. The next section provides a thorough overview of transition economies, innovation in transition economies and innovation through coopetition. The section following it describes the methodology. The section after that is presents the findings. The core findings of the study can be found in the subsection titled "Promising Areas of Research, Methods and Perspectives for Transition Economies", comprising promising areas of coopetition research, concepts and approaches for innovation in transition economies. The last section concludes the paper.

\section{Literature Review}

\section{Understanding the Transition Economies}

The term "transition economy" represents movement from a centrally planned economy to a market oriented economy. In other words, it is a renovation process in countries which move from a planned, public organizations-centered system to a private market economy. In this process, private ownership become more dominant and most of the resources are allocated through markets (Fischer \& Gelb, 1991).

Countries with transition economy are the countries that moved from a Soviet-type centrally planned system to a free and competitive market system (Svejnar, 2002). Some examples to transition economies in central Europe are Czech Republic, Hungary, Poland, Slovakia and Slovenia. This trend spread to South-Eastern Europe, influencing Albania, Romania Bulgaria and the former Yugoslavian republics, Crotia, Serbia, Montenegro, Bosnia and Herzegovina and North Macedonia. Russia and countries in the Commonwealth of Independent States (CIS) are also considered as transition economies. Among these mentioned countries, Albania was the last that moved from a centrally planned economy to a free market system in the beginning of the 90s (Xheneti \& Bartlett, 2012).

The main features of transition economies are transition from a government dominated market to free markets with higher competition, joining of foreign companies and reducing market power of domestic firms, foreign direct investment opportunities, high inequalities in life and work conditions, cultural and competitive tensions among the local and foreign rivals (OECD, 2012a, 2012b).

Transition economies provide economic liberalization and a move to an economy where the prices are set by market forces, rather than dictated by central institutions (Aidis, et al., 2008; Krammer, 2009). It is a complex process requiring thorough reforms in a country's economic, political and social institutions and infrastructure (Feige, 1994).

The main disadvantages of transition economies is the lack of financial capital, innovation management expertise and novel technology, while the advantages are high human capital and wide expertise in manufacturing activities (Apanasovich, Heras \& Parrilli, 2016).

\section{Innovation in Transition Economies}

This section describes the distinct conditions for innovation efforts in transition economies. United Nations (UN) determines global goals for 
development. In its 2030 agenda, there are 17 new Sustainable Development Goals (SDGs) for guiding policies and funding. Industry, innovation and infrastructure is listed as one of the goals, showing the integrated nature of these three elements.

Transition from a central and planned economy to a market oriented economy has gained particular interest of researchers since the 90s (Szerb \& Trumbull, 2016). Radical changes and reforms took place during the end of the 80 s and the beginning of the $90 \mathrm{~s}$ in transition economies increased the importance of entrepreneurship and innovation activities for research (Ratten, Ferreira \& Fernandes, 2017; Hisrich, Petković, Ramadani \& Dana, 2016; Peng, 2000).

The main drivers for growth, competitiveness and sustainability are identified as advanced technologies, larger information flow and organization's ability to innovate (EU, 2014; OECD, 2013). As an organization gets closer to becoming a global technology pioneer, the importance of innovation gets higher relative to imitation as a source of productivity growth (Acemoglu, Aghion \& Zilibotti, 2006).

A number of transition economies like Bulgaria, Hungary, Latvia, Poland, Romania and Slovakia with limited knowledge and innovation profile and performances are supported to adopt, imitate and innovate through new strategies, in the context of "European imitative innovation area" (Capello \& Lenzi, 2013).

At the initial stage of transition process, countries like Czech Republic, Hungary and Poland performed well in creation of new venture and support; but their innovation capabilities were insufficient to foster entrepreneurship (Szerb, 2008). The innovation experience and knowledge gap of the central and eastern European countries compared to developed countries caused less number of patents and other intellectual properties produced per capita (Marinova, 2001).

In the beginning of the 21st century, several transition economies implemented numerous policies to move from an imitation-based economy to an innovative entrepreneurial economy (Acs \& Szerb, 2007).
There was a high competition for the firms in transition economies, due to not only the domestic competitors, but also the other European companies, increasing the importance of innovation (González-Pernía, Parrilli \& PeñaLegazkue, 2015). In entrepreneurial approaches in transition economies, human capital and modern technology are used to gain competitive advantage for the companies (Peng, 2001). Presence of high quality human resources and adoption of modern technology are identified as the important factors of product innovation within companies. A study in an example transition economy, Slovenia, stated that firms with insufficient internal capabilities had a lower innovation capability (LeskovarSpacapan \& Bastic, 2007). One of the main challenges in adoption of modern technology by firms in transition economies is large costs of the required machinery and equipment, compared to companies in more developed economies in Europe (Apanasovich et al., 2016).

According to the study of World Bank (2010), instruments used for encouraging innovation may have both advantages and disadvantages. As an example, reducing barriers for importing goods and services can drop down prices to world average; while at the same time, reducing the competitive power of domestic firms. Foreign direct investment as another instrument will obviously increase competition, put pressure on local companies to innovate, increase local worker's knowledge and expertise. However, foreign firms may deploy harsh strategies such as buying domestic firms to eliminate local competition or working with some other global partners to cope with local supply and distribution needs. Another highlighted topic is easy access to foreign technology. It brings out the risk of causing domestic firms to not rely on their individual R\&D.

In a report of OECD (2012a, 2012b), the objectives of innovation are described according to different country categories. For low-income countries, it is stated that innovation should respond to specific local conditions in important industries. Moreover, inclusive innovation for and by low- and middle-income groups in the society is suggested to improve welfare and provide 
access to business opportunities. Regarding the middle-income countries at early stages of development, the priorities are listed as to focus on key areas to compete with leading world innovators through radical and incremental innovation and addressing issues at global scale. For later stages of development, climbing up in global value chains and keeping the competitiveness in the most successful industries of the country are listed as the important targets. The same report explains that there is a shift to service-based economies from manufacturingbased economies, with still sustaining importance of manufacturing in development. Information and communication technologies (ICTs) are the catalysts of efficient and higher scale innovation allowing many partners to work together easily.

Innovation policies are crucial for the process of including private companies in $R \& D$ activities in transition economies (OECD, 2012a, 2012b). Formerly, government and public laboratories based innovation system can be evolved through effective policies that integrate universities and firms. At the early stages, government can act as the main body of the innovation system, while at the later stages leaving most of its duties to private sector and paving the way to a decentralized innovation system. The same report shows the successful sectors and firms in emerging economies. The top 15 companies in 2011 are mainly from telecommunication, oil and gas, construction and electronics industries.

In transition economies, a high number of the domestic firms can have limited resources and flexibilities. Due to the various needs that can not be met by a single partner, these companies usually tend to join networks and ecosystems with high numbers of allies providing different resources and knowledge.

\section{Coopetition and Innovation}

The term "coopetition" represents the coexistence of competition and cooperation together between two or more parties, under specific circumstances (Sroka, 2013). One of its main advantages is the creation of new products more, compared to the cases where there is collaboration with non- competing parties (Tether, 2002; Quintana-Garcia \& Benavides- Velasco, 2004). This is achieved through the joint use of market and technological knowledge, allowing more effective generation and diffusion of innovation (Ritala \& HurmelinnaLaukkanen, 2009). Coopetition can be effective at the success of innovation. Coopetition with competitors who have identical or complementary solutions, skills and competences may be more beneficial (M. Zehir \& C. Zehir, 2019).

There are several works that show the evidences of collaboration of competing companies to innovate and bring new products, services and solutions to market (Gnyawali \& Park, 2011; Hung \& Chang 2012; Ritala \& Hurmelinna-Laukkanen 2009; Bouncken \& Kraus, 2013; Bouncken \& Fredrich, 2012; Pekovic, Grolleau, \& Mzoughi, 2020; Bouncken, Fredrich, Ritala, \& Kraus, 2018).

Coopetition is a driver of value creation in innovation activities, due to involved parties' aligning targets (Giachetti \& Dagnino, 2016; Le Roy \& Czakon, 2016), complementary resources and effective combination of industry- and marketspecific expertise and market power (Ritala \& Hurmelinna-Laukkanen, 2009; Gnyawali \& Park; 2011). Coopetition can enhance value appropriation through expanding the involved parties' current markets and helping development of new markets and business models (Ritala, Golnam \& Wegmann, 2014; Gast, Filser, Gundolf \& Kraus, 2015). An important benefit of coopetition is sharing of common knowledge about markets and technologies, which allows more effective creation of new knowledge and innovations (Belderbos, Carree \& Lokshin 2004; Dussauge, Garrette \& Mitchell 2000).

In transition economies, collaborations with foreign companies, especially with the ones with important technology licenses can have an important impact on product innovation (KurtishiKastrati, Ramadani, Dana \& Ratten, 2016). Through such relationships, local firms can learn about new product design and technology through reverse engineering and enhance their innovation activities, skilled and experienced staff of foreign firms can move to local firms (spillovers through labor market turnover) and the foreign companies' 
products can enhance local companies' creative thinking, new product and process designdevelopment skills (Cheung and Lin, 2004; Gërguri-Rashiti, Ramadani, Abazi-Alili, Dana \& Ratten, 2017; Ramadani, Abazi-Alili, Dana, Rexhepi \& Ibraimi, 2017). Through these ways, local companies in transition economies can gain valuable knowledge from other companies, improve their product portfolio and increase their performance.

Forming alliances with larger and more powerful organizations is one of the effective ways of coping with environmental turbulence in transition economies. Such alliances, can involve strong local firms along with foreign entrants and public agencies. Entrepreneurial local firms can get access to financial assets and learn useful managerial and technical capabilities from the foreign partners. Government agencies can provide useful resources especially to startups, helping to reduce environmental turbulence for entrepreneurs (Peng, 2001).

Companies in transition economies need the latest technology to be able to compete in global markets (Svetlicic \& Rojec 1994). However, they usually lack the related knowledge and competences to develop or adopt sophisticated manufacturing and product technologies. For this reason, they tend to seek alliances with possible partners that have the matching technological capabilities.

\section{Methodology}

As part of the methodology, firstly a comprehensive overview of works in transition economies is evaluated, depicting a conceptual framework. This highlighted the importance of innovation in transition economies and the ways to do it effectively in transition economy conditions. Coopetition is determined as an important, useful strategy for successful and effective innovation activities. In the next step, a bibliometric analysis is conducted to examine the research areas of both disciplines, representing their social, intellectual and conceptual structure (Verma \& Gustafsson, 2020).
Firstly, the keywords "coopetition" and "innovation" are searched together for the works in Web of Science database, resulting in 405 publications. A second search is done using the keywords "transition economies" and "innovation" together, resulting in 230 publications. The number of publications annually for the last decade is shown on a graph for each cluster of publications. After that, using VOSviewer tool, bibliometric mapping is done for both cluster of publications. The mapping is done for co-occurrence of keywords and countries of publications.

At the last stage, a number of outstanding works among the limited number of publications that cover all the three areas (coopetition, innovation and transition economies) together are presented in a table. All these activities, led to identification of promising areas of research, methods and perspectives that can be adopted from studies in innovation through coopetition in transition economies explained in "Promising Areas of Research, Methods and Perspectives for Transition Economies" subsection under "Findings".

\section{Findings}

\section{Bibliometric Analysis and Mapping}

Bibliometric analysis and mapping is done using data of the works found in Web of Science database, using VOSviewer. Figure 1 shows the number of publications on coopetition and innovation annually in the last decade. Especially in the recent years, the interest in and efforts on innovation activities through coopetition is considerably increased, as the number of publications exceeded 50 annually, more than the double of the works annually published before 2016. 


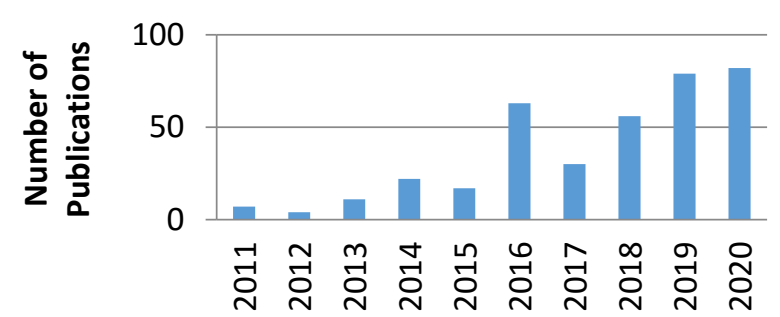

Year

Figure 1. The number of publications on coopetition and innovation in the last 10 years

The bibliometric map of top 50 keywords in coopetition and innovation studies is shown in Figure 2. Knowledge sharing, management and transfer are the knowledge-related important aspects considered in the previous works, while value creation and capture are prominent from the value perspective. Open innovation and radical innovation are the popular innovation views, while business ecosystem, entrepreneurial ecosystem and platforms come to the fore for coopetition networks with high number of parties. SMEs are at the spotlight of research, while banks and tourism are the widely investigated sectors. Trust, tensions, paradoxes, governance, sustainability and performance are the particularly focused aspects of the conducted innovation through coopetition activities.

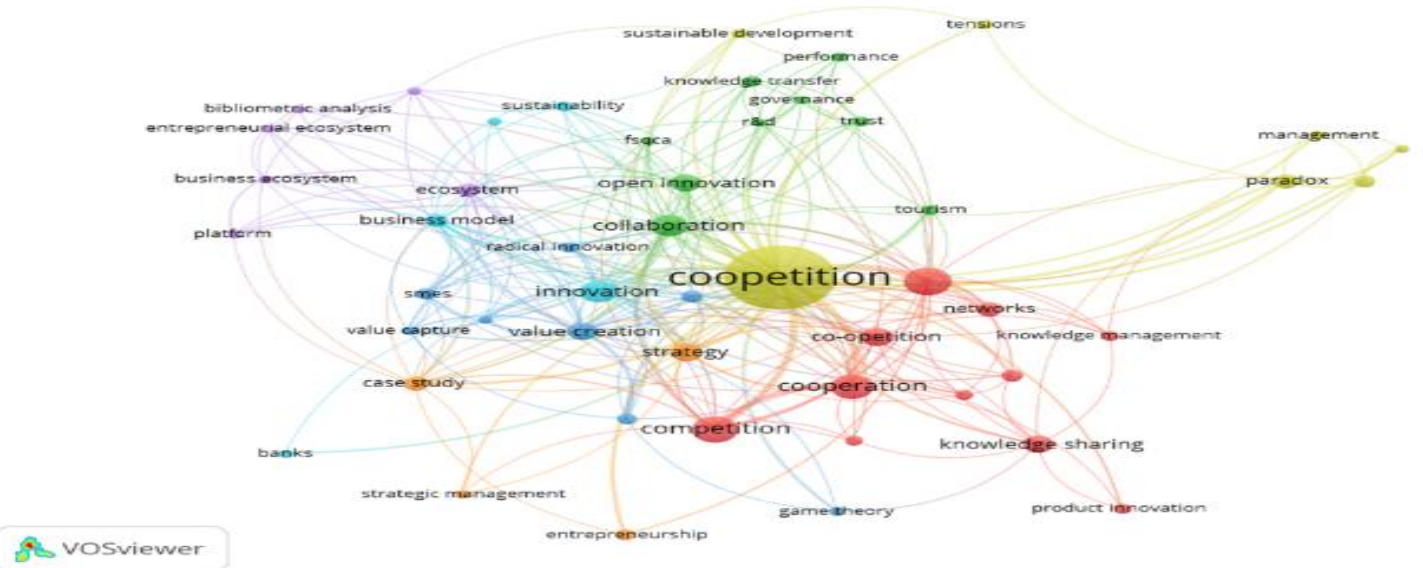

Figure 2. The bibliometric map of the top 50 research topics in coopetition and innovation studies

The bibliometric map of the related top 48 countries is provided in Figure 3. The researchers in the US have joint studies with the researchers from different parts of the world, such as China, South Korea, Italy, India, Austria and Turkey, while Germany mainly has joint activities with the Northern European countries and Spain has a research network with South America. France has research partnership with a number of Middle East.

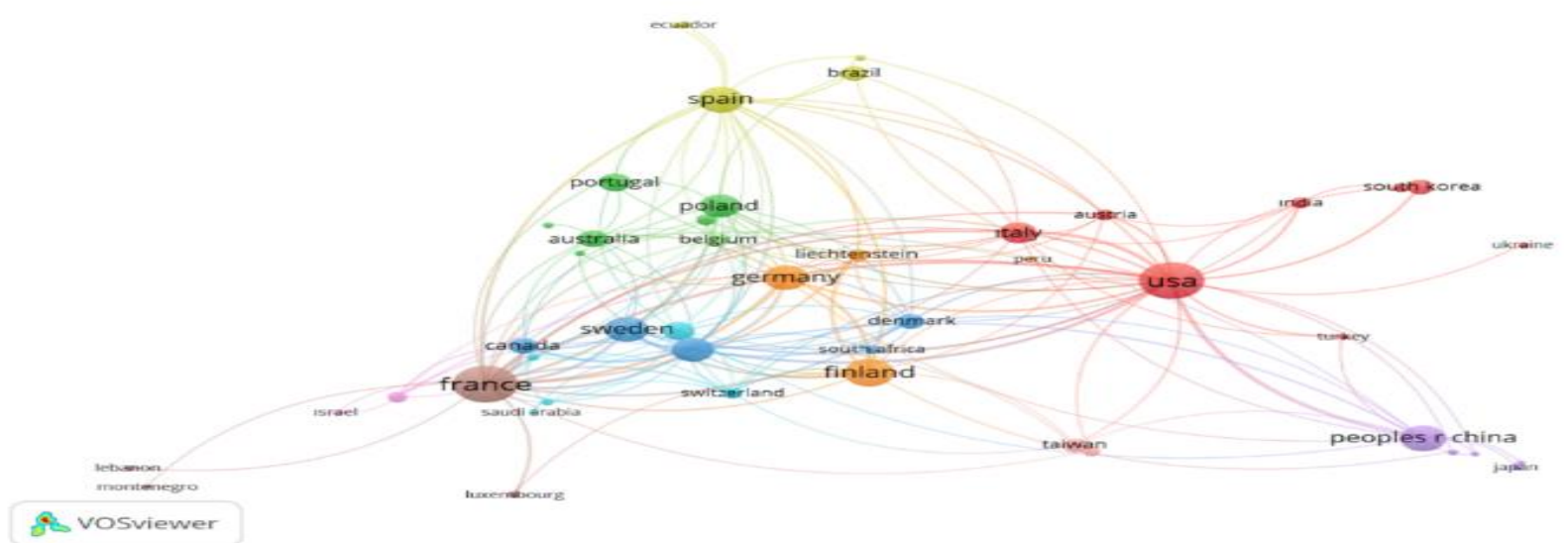

Figure 3. The bibliometric map of the 48 related author countries in coopetition and innovation studies 
The number of publications published on transition economy and innovation annually in the last decade is shown in Figure 4. A steady biennial growth trend is observed with relatively less number of works compared to the works on innovation and competition. The increasing trend shows the recent interest on innovation approaches specific to transition economies, while the low quantity of annual number of publications indicate the need for further efforts in this area.

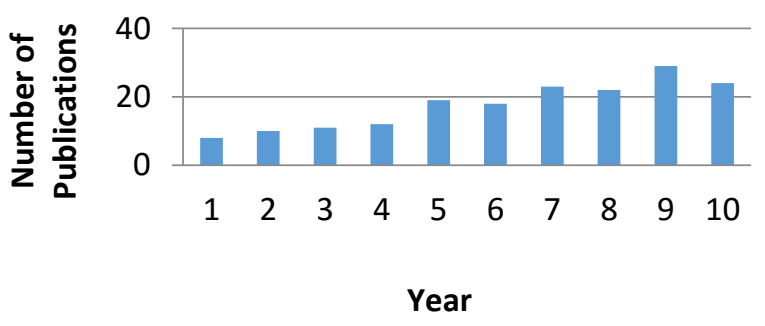

Figure 4. The number of publications on transition economies and innovation in the last 10 years
The bibliometric map of the top 50 keywords in studies on transition economies and innovation is shown in Figure 5. Internationalization, international entrepreneurship, foreign direct investment and export intensity are the main aspects considered when investigating the foreign companies entering a transition economy or domestic firms that expand beyond their countries. Absorptive capacity, spillover, knowledge management and mode of innovation are prominent when examining the interactions in joint activities between foreign and domestic parties working on innovation in transition economies. Productivity, competitiveness, development and performance are considered to evaluate the benefits of joint activities.

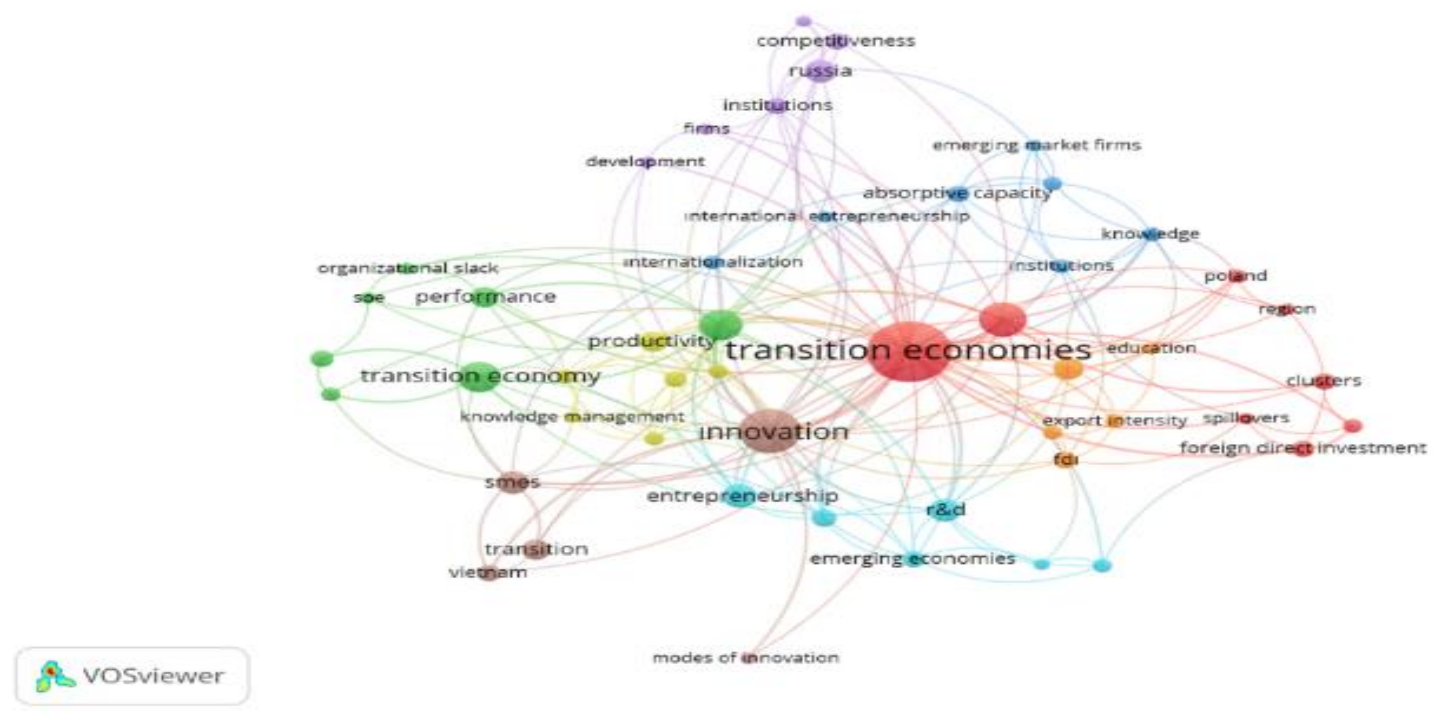

Figure 5. The bibliometric map of the top 50 research topics in transition economies and innovation studies

The related 46 countries are mapped in Figure 6. China, the US and England are at the heart of joint studies, while close collaboration is visible between Eastern European countries such as Serbia, Macedonia and Slovenia. The US has unique joint efforts with Turkey and Australia, while China has close cooperation with Singapore and an interesting collaboration is visible between England and Greece. 


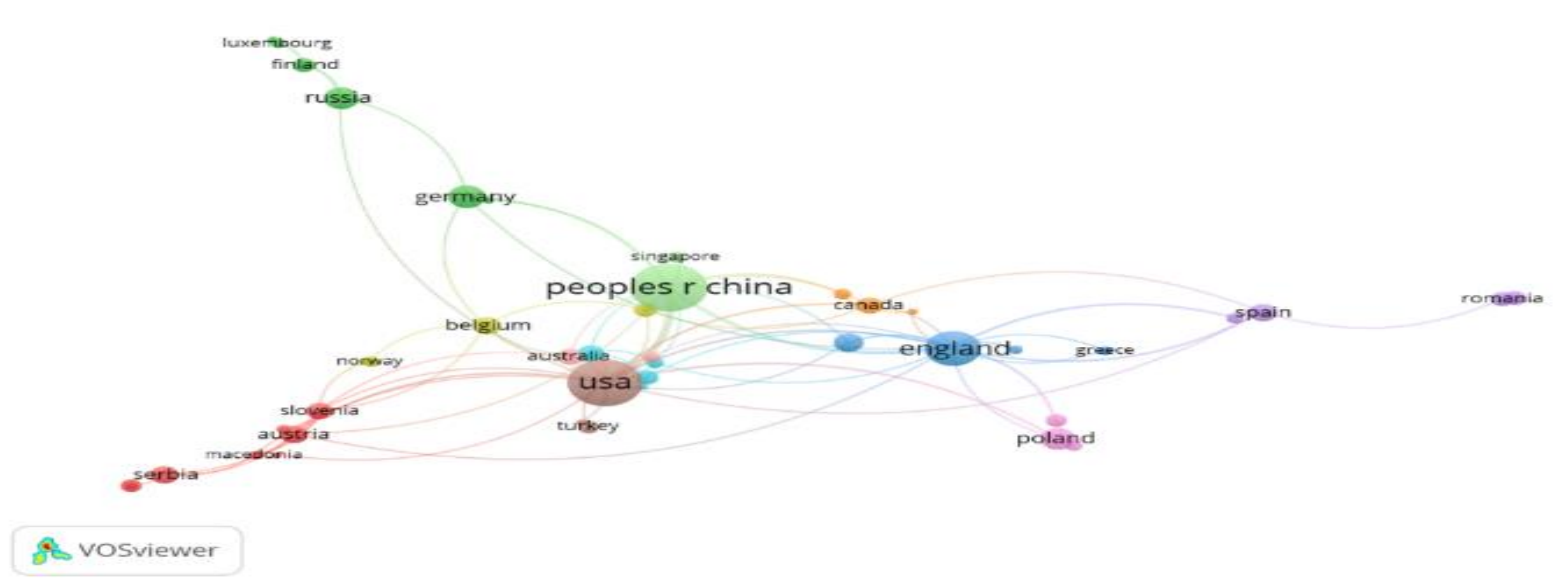

Figure 6. The bibliometric map of the 46 related author countries in coopetition and innovation studies

\section{Critical Evaluation of the Underlying Dynamics}

The works on innovation in the domain of coopetition and in the domain of transition economies, the limited number of works that cover both coopetition and transition economies are investigated. Table 1 presents the details of a number of prominent works, including their important findings.

Table 1. Prominent studies about coopetition and innovation in transition economies

\begin{tabular}{|c|c|c|c|c|}
\hline $\begin{array}{l}\text { Authors and } \\
\text { Year }\end{array}$ & Focus of Interest & Methods & Sample & Findings \\
\hline $\begin{array}{l}\text { Apanasovich, e } \\
\text { al., } 2016\end{array}$ & $\begin{array}{l}\text { Innovations in post-Soviet } \\
\text { transition economies (The } \\
\text { case of Belarus) }\end{array}$ & Data analysis & $\begin{array}{l}1261 \\
\text { manufacturing and } \\
\text { service firms }\end{array}$ & $\begin{array}{l}\text { Combination of science and technology-based innovation (STI) and } \\
\text { doing- using and interacting-based innovation (DUI) modes is more } \\
\text { effective at technology innovation compared to their individual use. } \\
\text { Preferring DUI mode individually is more effective at product } \\
\text { innovation than STI mode. DUI mode has a strong and positive } \\
\text { relationship with organization innovation. }\end{array}$ \\
\hline $\begin{array}{l}\text { Cygler \& Sroka, } \\
2016\end{array}$ & $\begin{array}{l}\text { Coopetition in Polish } \\
\text { Companies }\end{array}$ & Surveys & $\begin{array}{l}235 \text { companies } \\
\text { operating in the } \\
\text { high-tech sector }\end{array}$ & $\begin{array}{l}\text { Companies usually cooperate for sales, distribution and purchase } \\
\text { operations. They prefer coopetition mainly for primary activities rather } \\
\text { than support activities. }\end{array}$ \\
\hline \multicolumn{3}{|c|}{$\begin{array}{l}\text { Jankowska, 2011 Internationalization of PolishInterviews } \\
\text { firms }\end{array}$} & $\begin{array}{l}57 \text { companies in } \\
\text { several industries }\end{array}$ & $\begin{array}{l}\text { The firms that cooperate with their competitors increase has higher } \\
\text { international competitiveness. Firms, especially SMEs that prefer } \\
\text { coopetition increase their market share both in domestic and foreign } \\
\text { markets. }\end{array}$ \\
\hline $\begin{array}{l}\text { Gërguri-Rashiti, } \\
\text { et al., } 2017\end{array}$ & $\begin{array}{l}\text { Information communication } \\
\text { technologies, Innovation anc } \\
\text { Firm Performance in } \\
\text { transition economies }\end{array}$ & $\begin{array}{l}\text { Surveys and } \\
\text { probit model } \\
\text { (econometric } \\
\text { technique) }\end{array}$ & $\begin{array}{l}9,354 \text { firms in } \\
\text { several industries }\end{array}$ & $\begin{array}{l}\text { It is found that large companies in transition economies prefer } \\
\text { innovation activities more, compared to small firms. In case they have } \\
\text { competitive pressure from foreign firms, they tend to undertake more } \\
\text { innovation activities. Private-owned firms (both domestic and foreign) } \\
\text { with above } 10 \% \text { of ownership have more innovation activities } \\
\text { compared to state-owned companies. }\end{array}$ \\
\hline $\begin{array}{l}\text { Ramadani, et. } \\
\text { al., } 2019\end{array}$ & $\begin{array}{l}\text { Product innovation and firm } \\
\text { performance in transition } \\
\text { economies }\end{array}$ & $\begin{array}{l}\text { Data analysis } \\
\text { and multistage } \\
\text { equation } \\
\text { modeling. }\end{array}$ & $\begin{array}{l}6246 \text { companies in } \\
\text { several industries. }\end{array}$ & $\begin{array}{l}\text { Product innovation improves firm performance in transition } \\
\text { economies, based on firm size, total labor cost, capital and other } \\
\text { variables. On the other hand, age and informal sector competition have } \\
\text { negative impact on performance. }\end{array}$ \\
\hline $\begin{array}{l}\text { W. Przychodze } \\
\& \text { J. } \\
\text { Przychodzen, } \\
2020\end{array}$ & $\begin{array}{l}\text { Renewable energy } \\
\text { production in transition } \\
\text { economies }\end{array}$ & Data analysis & $\begin{array}{l}27 \text { Transition } \\
\text { economies }\end{array}$ & $\begin{array}{l}\text { More economic growth, increasing unemployment and government } \\
\text { debt increase renewable energy generation activities. Increasing CO2 } \\
\text { emissions per capita, competition policy and reduced competitiveness } \\
\text { in the energy market limits green energy generation from renewable } \\
\text { sources. After } 2007 \text { financial crisis, reinforcement of competition in } \\
\text { energy market and public subsidies increased deployment of renewable } \\
\text { generation. }\end{array}$ \\
\hline
\end{tabular}




\begin{tabular}{|c|c|c|c|c|}
\hline Hitt, et al., 2004 & $\begin{array}{l}\text { The Institutional Effects on } \\
\text { Strategic Alliance Partner } \\
\text { Selection in Transition } \\
\text { Economies: China vs. Russia }\end{array}$ & Surveys & $\begin{array}{l}121 \text { firms ( } 63 \text { firms } \\
\text { based in China and } \\
58 \text { firms based in } \\
\text { Russia ) }\end{array}$ & $\begin{array}{l}\text { Stable and supportive environment in China helps the domestic firms } \\
\text { to employ a longer-term plan for alliances and partners considering } \\
\text { their unique competences, technological and managerial capabilities. } \\
\text { On the other hand, relatively less stable institutional environment in } \\
\text { Russia, caused Russian managers to employ short term plans for } \\
\text { alliances and partner selection, considering access to financial capital } \\
\text { and complementary skills to cope better with the turbulent } \\
\text { environment. }\end{array}$ \\
\hline Vajjhala, 2013 & $\begin{array}{l}\text { Key Barriers to Knowledge } \\
\text { Sharing in Medium-Sized } \\
\text { Enterprises in Transition } \\
\text { Economies (Albania) }\end{array}$ & Surveys & $\begin{array}{l}118 \text { respondents } \\
\text { working in } 20 \\
\text { medium-sized } \\
\text { enterprises }\end{array}$ & $\begin{array}{l}\text { The main barriers to knowledge sharing for the SMEs in Albania are } \\
\text { cultural problems, motivational challenges, lack of human resources, } \\
\text { insufficient technological resources and lack of benefits. }\end{array}$ \\
\hline Dolinska, 2015 & $\begin{array}{l}\text { Knowledge based } \\
\text { coopetition in innovation } \\
\text { networks (in Poland) }\end{array}$ & Surveys & 64 companies & $\begin{array}{l}\text { The study states that innovation networks allow effective knowledge- } \\
\text { related development in innovative companies. } \\
\text { The research showed that all the considered companies cooperate with } \\
\text { others in their innovation processes. They dominantly }(95.4 \%) \\
\text { cooperate in their home countries, while less ( } 43.6 \%) \text { have collaboration } \\
\text { in both inside and outside their home countries and very few }(4.6 \%) \\
\text { prefer cooperation only abroad. }\end{array}$ \\
\hline
\end{tabular}

\section{Promising Areas of Research, Methods and Perspectives for Transition Economies}

This section represents the core contributions of the study. The promising areas of research, methods and perspectives are determined, based on the identified aspects in section 2 and considering the analyses done in section 3, encompassing innovation through coopetition and innovation in transition economies.

Globalisation as a consequence of trade openness and foreign direct investment, causes foreign competitors to enter to a developing market (OECD, 2012a, 2012b). Many of these new actors may have financial advantages and valuable know-how compared to domestic firms. However, they will mostly need local support, driving them to form local alliances especially for reliable supply chain relationships. Therefore, vertical coopetition studies are of importance for transition economies. Vertical alliances mostly lead to relatively less efficient and slower innovation compared to horizontal alliances, due to different knowledge bases of partners. It is also a threat for companies to face their partner as a rival during coopetition. Especially buyers have the probability to use seller's knowledge and technology to make a lower cost agreement with another supplier or even start self-production of formerly imported components. According to the study of Bouncken, Clauß \& Fredrich (2016), transactional governance (plans, contracts and etc.) may have a negative impact on innovation performance especially at the early stages of coopetition, while relational governance (moral control, cooperative atmosphere) has rather positive impact.

Participation of foreign companies in local markets also has a negative impact on the national companies' market power. This usually leads to an increase in competition and innovation activities of the domestic firms. This can be fostered through coopetition among the companies. Hereby, horizontal coopetition networks formed by only local companies or a mixture of domestic and foreign firms that can be investigated. A number of critical success factors for horizontal coopetition networks are proposed in the study of Petter, Resende, De Andrade Júnior \& Horst (2014). According to the study, trust and commitment among the partners have a major positive impact on the success of coopetition. Some other important factors are the synergy between the participants, organizational culture, exchange of experiences and learning, equity of rights and duties, management of conflicts and interdependences.

In the early stages of development in transition economies, R\&D activities are mostly conducted by public laboratories funded by the government. However, most of the developed economies rely on R\&D done by private companies in cooperation with universities, public institutions and the government. Therefore, it may be beneficial to 
study the impacts and management of coopetition between government and universities with private companies. It is indicated in the paper of Eriksson \& Pesamaa (2013) that, public clients can learn from private clients about valuable practices in project-based industries.

One of the frequent coopetition types in transition economies, from the perspective of firm size is SME-Large enterprise relationship. In the study of Krommendijk (2016), drivers, advantages and drawbacks according to this specific alliance type are discussed. The main drivers for SMELarge enterprise coopetition are described as access opportunity for the SME to value chains and development option of highly specialized products for the large enterprises. The advantages or positive outcomes of this kind of a coopetition for SMEs are increase in their legitimacy and credibility, and enlarged competencies and sources for large enterprises. Increase in acquisition power is a mutual benefit for both of the partners as a result of coopetition of SMEs with local expertise and customer portfolio with large enterprises with a broader and international market power. On the other hand, there are also drawbacks such as power asymmetry, risk of losing independence and slowed down decision making. Power asymmetry consideration and management is more crucial for SMEs, since large companies usually gain superior economic benefits from coopetition. Role flexibility is one of the possible ways of coping with power asymmetry, based on forming different alliances with different companies over a long term to develop innovative products to improve competency.

Transition economies are usually described as turbulent and dynamic environments, where firms may form several alliances over time and change their coopetition partners as a response to changing conditions. For this reason, performance analysis and case studies require consideration of numerous coopetition activities of the company with different partners. Longitudinal case studies, as a recently emerging approach in coopetition literature can be useful for analysis. In these studies, usually a single or a number of companies are focused on and their coopetition activities with different allies over a long time period are analyzed. As indicated in the work of Chiambaretto \& Fernandez (2016), market uncertainty is one of the main drivers of evolution of alliance portfolio. Diversity can provide access to new sources and markets; but can bring together management challenges. According to the findings of the study, firms tend to form horizontal and mixed alliances in the times of high market uncertainty. In the times of low uncertainty, they mostly exit coopetitive alliances with tensions and prefer vertical alliances with rather smaller number of companies. It is also stated that the best partner of a firm to access specific resources and markets is its closest competitor.

A big percentage of the studies in the literature focus on specific industries in a country selected by the authors. Similar to this trend, there are specific sectors that includes top companies with successful innovation activities. In the report of $\operatorname{OECD}(2012 a, 2012 b)$, the top firms in emerging economies are from telecommunication, oil and gas, construction, electronics and automobile industries. Considering the majority of the works, there is lack of coopetition studies in the oil and gas industry. The majority of the industry based coopetition studies is based on data analysis of numerous firms to evaluate inter-firm coopetition outcomes.

Innovation is not only limited to high-tech and manufacturing industries. Especially in transition economies, sectors with advanced technology and manufacturing need high investments and comprehensive know-how. However, other sectors (such as service and food) also have a high potential for innovation, with rather less investment and know-how. There are studies in the literature on food, wine, sport and tourism, mostly based on case studies comprising small number of SMEs (Galdeano-Gómez, CéspedesLorente \& Rodríguez-Rodríguez, 2006; Granata, Géraudel, Gundolf, Gast \& Marques, 2016). Surveys are mostly preferred in these studies to investigate business model innovation, value creation and competitive advantage.

Inclusive innovation is one of the distinguished type of innovation in the countries with transition economies. These countries have more inequalities 
in society, causing specific local needs by low- and middle income customers that drive inclusive innovation to improve social welfare. One type of inclusive innovation is on developing cheaper and simplified products for lower income groups to reduce the gap between rich and poor. Another type is mainly on business models to engage lower income groups in innovation activities and entrepreneurship. There is also lack of studies in the literature about inclusive innovation and coopetition. Coopetition between government, universities and private sector for providing solutions to local issues through innovation, represents a useful basis for case study formations.

One of the main challenges in transition economies is limited amount of investment in innovation activities. In specific cases, this may be a main barrier in front of new products and services. A promising low cost approach is crowdsourcing, where interested audiences from public can even contribute to innovation. The contribution can be either on a voluntarily basis or to gain individual output related social and/or monetary incentives. Crowdsourcing is mostly for idea creation and end-user product innovation. While idea creation represents one of the initial phases of innovation for the crowdsourcing companies, end-user product innovation allow them to design their new products according to customer desires. There are different focuses in crowdsourcing articles. While Zhao, Renard, Elmoukhliss \& Balague (2016) investigates the factors that influence creative performance, $\mathrm{Wu}, \mathrm{Li}$ \& Chang (2015) discusses the importance of social media in social learning process. Apart from these perspectives, Majchrzak \& Malhotra (2013) studies information systems considering participation architectures. One of the important findings in the paper of Zhao et al (2016) is that coopetition is more fruitful regarding the number and creativity of ideas in crowdsourcing.

Understanding of coopetition outcomes is one of the efforts in many studies. Similarly, in transition economies, it would be crucial to examine the innovation performance of foreign company-domestic firm coopetition cases. In order to achieve it, an emerging approach in the literature is patent analysis. As a basic example, in the report of OECD (2012a, 2012b), openness benefits are illustrated based on the number of patents with co-inventors. It is indicated in Chen \& Chen (2011), that patent analysis provides more information than financial statements. The methods used in that study is to count the number of patents, categorize according to the technological fields and citation analysis. In the study of Park, Srivastava \& Gnyawali (2014) patent analysis is used together with alliance data to identify the impact of cooperation and competition intensities on firm innovation performance.

\section{Discussions and Conclusion}

This study revealed a number of applicable ideas and approaches of innovation through coopetition in transition economies. The explored concepts in section 2 provided deep insights into the general framework, characteristic features and explicit study patterns. Detailed interpretation of the focuses areas in innovation through coopetition works and innovation in transition economies works in section 3 paved the way for identification of the suitable and promising study elements in "Promising Areas of Research, Methods and Perspectives for Transition Economies" subsection under "Findings".

According to the study findings, the prominent approaches are, vertical coopetition between the foreign newcomers and local competitors, horizontal coopetition networks formed by both foreign companies and domestic firms or only local companies, coopetition between government, universities and private sector, SME-Large enterprise coopetition activities and risks, longitudinal case studies to observe alliance evolutions, analysis of specific industries and companies that are

Successful at innovation and benefit from coopetition in transition economies, analysis of coopetition in sectors different from manufacturing and without high technology needs (such as food, tourism, sports and etc.), inclusive innovation opportunities through innovation, crowdsourcing with coopetition, patent analysis 
for evaluating innovation performance. On the other hand, there is lack of studies that focus on sectors and case studies in these economies. Effective adoption of coopetition literature experiences for future studies in transition economies can open new doors for innovation, improve the understanding of coopetition challenges and foster research activities to increase innovation performance in accordance with firm competitiveness. The future work will be on coopetition case studies comprising government, universities and private companies in transition economies, development of scales for the analysis of detailed dynamics between coopetitors and investigation of effective strategies in the field of coopetition for innovation.

\section{References}

Aidis, R., Estrin, S. and Mickiewicz, T. (2008). Institutions and entrepreneurship development in Russia: A comparative perspective. Journal of Business Venturing, 23(6), 656-672.

Acemoglu, D., Aghion, P. and Zilibotti, F. (2006). Distance to frontier, selection, and economic growth. Journal of the European Economic Association, 4(1), 37-74.

Acs, Z. J. and Szerb, L. (2007). Entrepreneurship, economic growth and public policy. Small Business Economics, 28(2), 109-122.

Apanasovich, N., Heras, H. A. and Parrilli, M. D. (2016). The impact of business innovation modes on SME innovation performance in post-Soviet transition economies: The case of Belarus. Technovation, 57, 30-40.

Belderbos, R., Carree, M. and Lokshin, B. (2004). Cooperative $R \& D$ and firm performance. Research Policy, 33(10), 1477-1492.

Bengtsson, M. and Kock, S. (2014). Coopetition-Quo vadis? Past accomplishments and future challenges. Industrial Marketing Management, 43(2), 180-188.

Bengtsson, M. and Raza-Ullah, T. (2016). A systematic review of research on coopetition: Toward a multilevel understanding. Industrial Marketing Management, 57, 23-39.

Bengtsson, M., Raza-Ullah, T., \& Vanyushyn, V. (2016). The coopetition paradox and tension: The moderating role of coopetition capability. Industrial Marketing Management, 53, 19-30.

Bouncken, R. B. and Fredrich, V. (2012). Coopetition: performance implications and management antecedents. International Journal of Innovation Management, 16(05), 1250028.

Bouncken, R. B. and Kraus, S. (2013). Innovation in knowledge-intensive industries: The doubleedged sword of coopetition. Journal of Business Research, 66(10), 2060-2070.

Bouncken, R. B., Gast, J., Kraus, S. and Bogers, M. (2015). Coopetition: a systematic review, synthesis, and future research directions. Review of Managerial Science, 9(3), 577-601.

Bouncken, R. B., Fredrich, V., Ritala, P. and Kraus, S. (2018). Coopetition in new product development alliances: advantages and tensions for incremental and radical innovation. British Journal of Management, 29(3), 391-410.

Capello, R. and Lenzi, C. (2013). Territorial patterns of innovation: a taxonomy of innovative regions in Europe. The Annals of Regional Science, 51(1), 119-154.

Chen, Y. S. and Chen, B. Y. (2011). Utilizing patent analysis to explore the cooperative competition relationship of the two LED companies: Nichia and Osram. Technological Forecasting and Social Change, 78(2), 294-302.

Cheung, K. Y. and Ping, L. (2004). Spillover effects of FDI on innovation in China: Evidence from the provincial data. China Economic Review, 15(1), 25-44.

Cygler, J. and Sroka, W. (2016). The boundaries of coopetition: A case study of polish companies operating in the high-tech sector. In Economic Development and Entrepreneurship in Transition Economies (p.253-269). Springer, Cham.

Dolińska, M. (2015). Knowledge based development of innovative companies within the framework of innovation networks. Innovation, 17(3), 323-340.

Dussauge, P., Garrette, B., \& Mitchell, W. (2000). Learning from competing partners: Outcomes and durations of scale and link alliances in Europe, North America and Asia. Strategic Management Journal, 21(2), 99-126.

EU, (2014). Final Report from the expert group on retail sector innovation. European Commission, Brussels. Retrieved on 
02.05.2021

from

https://op.europa.eu/en/publication-detail/-

/publication/bcdb70b6-f733-4f1c-866b-

94a8195aab12/language-en

Feige, E. L. (1994). The underground economy and the currency enigma. Public Finance= Finances Publiques, 49(Supplement), 119-136.

Fischer, S. and Gelb, A. (1991). The process of socialist economic transformation. Journal of Economic Perspectives, 5(4), 91-105.

Galdeano-Gómez, E., Céspedes-Lorente, J. and Rodríguez-Rodríguez, M. (2006). Productivity and environmental performance in marketing cooperatives: An analysis of the Spanish horticultural sector. Journal of Agricultural Economics, 57(3), 479500.

Gast, J., Filser, M., Gundolf, K. and Kraus, S. (2015). Coopetition research: towards a better understanding of past trends and future directions. International Journal of Entrepreneurship and Small Business, 24(4), 492-521.

Gërguri-Rashiti, S., Ramadani, V., Abazi-Alili, H., Dana, L. P. and Ratten, V. (2017). ICT, innovation and firm performance: the transition economies context. Thunderbird International Business Review, 59(1), 93-102.

González-Pernía, J. L., Parrilli, M. D. and PeñaLegazkue, I. (2015). STI-DUI learning modes, firm-university collaboration and innovation. The Journal of Technology Transfer, 40(3), 475-492.

Gnyawali, D. R. and Park, B. J. R. (2011). Co-opetition between giants: Collaboration with competitors for technological innovation. Research Policy, 40(5), 650-663.

Granata, J., Géraudel, M., Gundolf, K., Gast, J. and Marques, P. (2016). Organisational innovation and coopetition between SMEs: a tertius strategies approach. International Journal of Technology Management, 71(1-2), 8199.

Hisrich, R. D., Petković, S., Ramadani, V. and Dana, L. P. (2016). Venture capital funds in transition countries: Insights from Bosnia and Herzegovina and Macedonia. Journal of Small Business and Enterprise Development, 23(2), 296-315.
Hitt, M. A., Ahlstrom, D., Dacin, M. T., Levitas, E. and Svobodina, L. (2004). The institutional effects on strategic alliance partner selection in transition economies: China vs. Russia. Organization Science, 15(2), 173-185.

Hung, S. W. and Chang, C. C. (2012). A co-opetition perspective of technology alliance governance modes. Technology Analysis $\mathcal{E}$ Strategic Management, 24(7), 679-696.

Jankowska, B. (2011). Implications of coopetition for international competitiveness and internationalization of firms: perspective of SME and large companies. International Journal of Business and Management Studies, 3(1), 49-58.

Krammer, S. M. (2009). Drivers of national innovation in transition: Evidence from a panel of Eastern European countries. Research Policy, 38(5), 845-860.

Krommendijk K. (2016). Differences in coopetition due to firm size. In Proceedings of the 8th IBA Bachelor Thesis Conference, Enschede, The Netherlands. Retrieved on 10.01.2021. Available at: http://essay. utwente. nl/71653 /1/ Krom mendijkBABMS.pdf

Kurtishi-Kastrati, S., Ramadani, V., Dana, L. P. and Ratten, V. (2016). Do foreign direct investments accelerate economic growth? The case of the Republic of Macedonia. International Journal of Competitiveness, 1(1), 71-98.

Leskovar-Spacapan, G. and Bastic, M. (2007). Differences in organizations' innovation capability in transition economy: Internal aspect of the organizations' strategic orientation. Technovation, 27(9), 533-546.

Loebbecke, C., Van Fenema, P. C. and Powell, P. (2016). Managing inter-organizational knowledge sharing. The Journal of Strategic Information Systems, 25(1), 4-14.

Majchrzak, A. and Malhotra, A. (2013). Towards an information systems perspective and research agenda on crowdsourcing for innovation. The Journal of Strategic Information Systems, 22(4), 257-268.

Marinova, D. (2001). Eastern European patenting activities in the USA. Technovation, 21(9), 571584.

OECD. (2012a). Innovation for development: A discussion of the issues and an overview of 
work of the OECD Directorate for Science, Technology and Industry. Publications. Retrieved on 08.05.2021 from http://www.oecd.org/innovation linno/50586251.pdf.

OECD. (2012b). OECD Science, Technology and Industry Outlook 2012, Part II Chapter 4: Innovation for development: The challenges ahead. Publications. Retrieved on 06.05.2021 from http://www.oecd.org/ innovation/inno/50586251.pdf.

OECD, (2013). Science, Technology and Industry Scoreboard 2013. OECD Publishing, Paris. Retrieved on 08.05.2021 from https://www.oecd-ilibrary.org/science-andtechnology/oecd-science-technology-andindustry-scoreboard-2013_sti_scoreboard-2013en

Park, B. J. R., Srivastava, M. K. and Gnyawali, D. R. (2014). Walking the tight rope of coopetition: Impact of competition and cooperation intensities and balance on firm innovation performance. Industrial Marketing Management, 43(2), 210-221.

Pekovic, S., Grolleau, G. and Mzoughi, N. (2020). Coopetition in innovation activities and firms' economic performance: An empirical analysis. Creativity and Innovation Management, 29(1), 85-98.

Peng, M. W. (2000). Business strategies in transition economies. London: Sage.

Peng, M. W. (2001). The resource-based view and international business. Journal of Management, 27(6), 803-829.

Petter, R. R. H., Resende, L. M., De Andrade Júnior, P. P. and Horst, D. J. (2014). Systematic review: an analysis model for measuring the coopetitive performance in horizontal cooperation networks mapping the critical success factors and their variables. The Annals of Regional Science, 53(1), 157-178.

Przychodzen, W. and Przychodzen, J. (2020). Determinants of renewable energy production in transition economies: A panel data approach. Energy, 191, 116583.

Quintana-Garcia, C. and Benavides-Velasco, C. A. (2004). Cooperation, competition, and innovative capability: A panel data of European dedicated biotechnology firms. Technovation, 24(12), 927-938.
Ramadani, V., Abazi-Alili, H., Dana, L. P., Rexhepi, G. and Ibraimi, S. (2017). The impact of knowledge spillovers and innovation on firm-performance: findings from the Balkans countries. International Entrepreneurship and Management Journal, 13(1), 299-325.

Ramadani, V., Hisrich, R. D., Abazi-Alili, H., Dana, L. P., Panthi, L. and Abazi-Bexheti, L. (2019). Product innovation and firm performance in transition economies: A multi-stage estimation approach. Technological Forecasting and Social Change, 140, 271-280.

Ratten, V., Ferreira, J. J. and Fernandes, C. I. (2017). Balkans entrepreneurship: the role of internal and external knowledge for business creation. World Review of Entrepreneurship, Management and Sustainable Development, 13(2-3), 126-140.

Ritala, P. and Hurmelinna-Laukkanen, P. (2009). What's in it for me? Creating and appropriating value in innovation-related coopetition. Technovation, 29(12), 819-828.

Ritala, P., Golnam, A. and Wegmann, A. (2014). Coopetition-based business models: The case of Amazon.com. Industrial Marketing Management, 43(2), 236-249.

Ritala, P., Kraus, S. and Bouncken, R. B. (2016). Introduction to coopetition and innovation: contemporary topics and future research opportunities. International Journal of Technology Management, 71(1-2), 1-9.

Sroka, W. (2013). Coopetition in the steel industryAnalysis of coopetition relations in the value net. Metalurgija, 52(1), 127-130.

Sternberg, R. and Wennekers, S. (2005). Determinants and effects of new business creation using global entrepreneurship monitor data. Small Business Economics, 24(3), 193-203.

Svejnar, J. (2002). Transition economies: Performance and challenges. Journal of Economic Perspectives, 16(1), 3-28.

Svetličič, M. and Rojec, M. (1994). Foreign direct investment and the transformation of Central European economies. MIR: Management International Review, 34(4), 293-312.

Szerb, L. (2008). The examination of the level of entrepreneurship in eight central Eastern European Countries. In Proceedings-6th International Conference on Management, Enterprise and Benchmarking (MEB 2008) 
(p.69-83). Óbuda University, Keleti Faculty of Business and Management.

Szerb, L. and Trumbull, W. N. (2016). The development of entrepreneurship in the European transition countries: Is transition complete?. Strategic Change, 25(2), 109-129.

Tether, B. S. (2002). Who co-operates for innovation, and why: an empirical analysis. Research Policy, 31(6), 947-967.

Vajjhala, N. R. (2013). Key barriers to knowledge sharing in medium-sized enterprises in transition economies. International Journal of Business and Social Science, 4(14), 90-98.

Verma, S. and Gustafsson, A. (2020). Investigating the emerging COVID-19 research trends in the field of business and management: A bibliometric analysis approach. Journal of Business Research, 118, 253-261.

World Bank. (2010). World Development Indicators 2010. The World Bank. Retrieved on 06.05.2021 from https://documents.worldbank.org/en/publication /documentsreports/documentdetail/988271468149678303/w orld-development-indicators-2010

Wu, Y. Li, E. Y. and Chang, W. (2015). Nurturina user creative performance in social media networks: an integration of habit of use with social capital and information exchange theories. Internet Research, 26(4), 869-900.
Xheneti, M. and Bartlett, W. (2012). Institutional constraints and SME growth in postcommunist Albania. Journal of Small Business and Enterprise Development, 19(4), 607-626.

Zehir, M. \& Zehir, C. (2019). Investigation of the relationship between market orientation, coopetition, innovation capabilities and firm performance. The European Proceedings of Social \& Behavioural Sciences, 75, 163-174.

Zhao Z, Renard D, Elmoukhliss M and Balague C. (2016). What affects creative performance in idea co- creation: competitive, cooperative or coopetitive climate? International Journal of Innovation Management, 20(4), 1-24. 